\title{
1, 2 en 3 Johannes: ' $n$ Oorsig van die huidige stand van navorsing oor die inleidingsvraagstukke
}

\author{
Author: \\ Jan van der Watt ${ }^{1,2}$ \\ Affiliations: \\ ${ }^{1}$ Department of New \\ Testament Exegesis \\ and Source Texts of \\ Christianity, Radboud \\ University, The \\ Netherlands \\ ${ }^{2}$ Department New \\ Testament, University of \\ the Free State, South Africa \\ Note: \\ Prof. Jan van der Watt is \\ a research associate of \\ the Department of New \\ Testament at the University \\ of the Free State, he is \\ also a professor in the \\ Department of the New \\ Testament at the Radboud \\ University, Nijmegen, The \\ Netherlands.
}

Correspondence to:

Jan van der Watt

email:

janvanderwatt@kpnmail.nl

Postal address:

Paterserf 7, 6584GA

Molenhoek, The

Netherlands

Dates:

Received: 25 May 2010

Accepted: 03 July 2010

Published: 07 June 2011

How to cite this article: Van der Watt, J., 2011,

' 1 , 2 en 3 Johannes: ' $n$

Oorsig van die huidige

stand van navorsing oor

die inleidingsvraagstukke',

HTS Teologiese Studies/

Theological Studies 67(1),

Art. \#867, 7 pages. DOI:

10.4102/hts.v67i1.867

(C) 2011. The Authors. Licensee: OpenJournals Publishing. This work is licensed under the Creative Commons Attribution License.
1, 2 and 3 John: An overview of the current state of research on the introductory questions

This article has presented an overview of the most important positions taken on certain introductory issues related to 1, 2 and 3 John. The article has not focussed on the detailed discussion of problems, but has rather provided a broad overview of the most important current positions. A typical characteristic of the introductory questions is their interrelatedness. The research inter alia examined the way in which decisions about the relation between the Gospel and Letters of John influence the question of authorship or the place and date of the Letters and how decisions about the level of conflict in the Letters influence their sequence.

\section{Inleiding}

Die Johannesbriewe is nie 'n fokuspunt in Nuwe-Testamentiese navorsing nie. Tog het daar die afgelope tyd wel 'n hele aantal nuwe kommentare op die Briewe verskyn. Dit is egter nie noodwendig toe te skryf aan hernude belangstelling in die Briewe nie, maar eerder dat verskeie uitgewers nuwe kommentaarreekse begin het of bestaande kommentaarreekse vernuwe. Die algemene tendens in die verlede was egter dat as iemand ' $n$ kommentaar op die Johannesevangelie geskryf het, die Johannesbriewe ook aangepak is. Dít het tot uitstekende kommentare op die Briewe gelei, byvoorbeeld dié van Brown (1982), Bultmann (1973) en Schnackenburg (1992). Dié kommentare is deur die ewe goeie bydraes van outeurs soos Klauck (1991) en Wengst (1978) aangevul. Meer onlangs het kommentare van byvoorbeeld Kruse (2000), Painter (2002), Lieu (2008), Yarbrough (2008), Menken (2010), en andere, belangstelling in die Briewe aangewakker. Verskeie goeie inleidings, soos dié van Brown (1997), Köstenberger (2009) en Schnelle (1999), bevat ook nuttige informasie.

In die lig hiervan bied hierdie artikel 'n breë oriëntering met betrekking tot die huidige stand van die navorsing oor die inleidingsvraagstukke van die drie Johannesbriewe. Die doel is om 'n oorsig te gee en nie om in detailvraagstukke vas te val nie. Detailbesprekings kan in die kommentare en inleidings gelees word en sal nie hier in besonderhede aandag ontvang nie. ${ }^{1}$

\section{Die Johannesbriewe was dokumente}

Die name van die outeur(s) van 1, 2 en 3 Johannes word nie in die dokumente genoem nie, maar sedert die einde van die 2de eeu, toe Irenaeus twee Briewe (waarskynlik 1 en 2 Johannes) en die Evangelie onder die naam Johannes, die seun van Sebedeus, met mekaar verbind het, is dié drie dokumente as Johannese dokumente bekend. Die Brief 3 Johannes is later vanweë sy ooreenstemmings met 2 Johannes tot die trilogie bygevoeg.

In die kanon is die drie Briewe later met vier ander, naamlik 1 en 2 Petrus, Jakobus en Judas, onder die naam Katolieke, of 'Algemene Briewe', verbind. Dít het daartoe bygedra dat die dokumente as 'briewe' gesien is - 'n opinie wat tot in die 18de eeu byna algemeen aanvaar is. Daar bestaan selfs vandag nie twyfel dat 2 en 3 Johannes antieke briewe is nie. Albei begin met tradisionele antieke groetformules en eindig met groete. Dieselfde geld egter nie vir 1 Johannes nie: Hier ontbreek die formele patroon van ' $n$ antieke brief. Aangesien dit nie soos ' $n$ brief lyk nie, word die vraag dikwels gestel: Wat sou die genre van 1 Johannes dan wees? Daar is geen tekort aan suggesties nie. Die suggesties is dit meestal eens dat 1 Johannes as ' $n$ dokument gesien word wat versprei is ten einde die ortodokse posisie van die outeur te konsolideer, en om misverstande oor die interpretasie van die Evangelie te probeer korrigeer. Wat die presiese aard van die dokument is, is die onderwerp van hewige debatte: Sommige dink aan 'n preek, 'n opstel of lesing, kommentaar of instruksies. So gaan die suggesties voort, sonder om werklik nuttige vrugte af te

1. ' $n$ Oorsigsartikel stel sy eie eise. Dit moet die breë lyne van die navorsing trek eerder as om in kleiner detailbesprekings vas te val. Daar sal ook nie voortdurend gemeld word wie watter standpunt inneem nie. Dít sou net op lang lyste verwysings en bladsynommers uitloop en is nie die bedoeling van hierdie artikel nie. Hier en daar word tog na bepaalde bronne verwys, maar aangesien van die sake deurlopend in die kommentare en inleidings ter sprake kom, word bladsynommers nie in elke geval gegee nie. 
werp. Daar word dikwels net op sekere funksionaliteite van die teks gekonsentreer (Klauck 1991:30). Klauck (1991:30-32) wys daarop dat om die funksionaliteit van die dokument te beskryf nie gelyk is aan die vasstelling van die genre van die geskrif nie, hoewel die twee mekaar natuurlik nie uitsluit nie. Daar wás pogings om hierdie probleem te probeer oplos deur tussen 'epistels' en 'briewe' te onderskei. 'Briewe' sou dan egte briewe wees wat aan spesifieke mense in spesifieke situasies geskryf is, terwyl 'epistels' as ' $\mathrm{n}$ soort opstel eerder op 'n meer algemene gehoor afgestem was. Na aanleiding hiervan sou 1 Johannes dus ' $n$ epistel wees en 2 en 3 Johannes Briewe. Hierdie onderskeid word egter nie meer as so geldig beskou nie, en die begrippe 'epistels' en 'briewe' word in baie gevalle eenvoudig as sinonieme gebruik (Lieu 2008; deSilva 2004). 'n Ander uitweg wat ook aansienlike steun geniet, is dat - ten spyte van die tekort aan formele eienskappe van ' $n$ antieke brief - die persoonlike, vriendelike toon in die geskrif; die duidelike betrokkenheid by die situasie waarin die ontvangers hulle bevind, en die oënskynlike poging van die outeur om die afstand met die ontvangers te oorbrug, 1 Johannes tog heel naby bring aan dit wat ' $n$ brief eintlik moet wees (Klauck 1991; Menken 2010; Köstenberger 2009), selfs al was dit bedoel om wyer as net die aanvanklike ontvangers versprei te word.

Hoe is die Briewe gestruktureer? In die geval van die korter Briewe, naamlik 2 en 3 Johannes, is daar weinig probleme om die struktuur vas te stel. Die Brief 2 Johannes het ' $n$ inleiding en slot (1-3 en 12-13), met ' $n$ inhoud wat in twee verdeel kan word (4-6 en 7-11). Die Brief 3 Johannes het eweneens ' $n$ inleiding en slot (1-4 en 13-14), terwyl die inhoud aan die hand van die temas wat aan bod kom, in drie verdeel kan word (5-8, 9-10 en 11-12).

Hoewel dit nie so eenvoudig is om 'n gemotiveerde en sinvolle strukturele verdeling vir 1 Johannes vas te stel nie, ontbreek dit tog nie aan voorstelle nie (kyk Akin 2001:3747 vir 'n oorsig). Suggesties strek van ' $\mathrm{n}$ tweedeling (bv. Akin 2001; Brown 1982; Smalley 1984) en 'n driedeling (bv. Schnackenburg 1992) tot 'n sewedeling (Lohmeyer 1928; Strecker 1996) en selfs meer (bv. Bruce 1979; Guthrie 1990), terwyl ander selfs 'n giastiese struktuur voorstel (Menken 2010). Die rede hiervoor lê waarskynlik in die tipiese sikliese Johannese argumentasiestyl sowel as die naatlose oorgange waarmee die outeur van een tema na ' $n$ ander in sy Briewe beweeg. Daar moet uiteindelik erken word dat daar geen vorm van konsensus oor die strukturele indeling van 1 Johannes bestaan nie.

Ten spyte van die gebrek aan duidelike struktuur in 1 Johannes, bestaan daar redelike konsensus oor die inhoud van die Brief. Kleiner temas kan wél onderskei word, maar die hooftemas waarom die inhoud van die brief ontwikkel word, is die Christologie en morele gedrag. Die Christologie draai om Jesus as Messias wat vlees geword het (1 Joh 2:2223; 2 Joh 7-9) en wie se bloed as versoening vir die sonde van die wêreld dien (1 Joh 1:7; 2:2; 4:10; 5:6). Die aanvaarding van Christus plaas die gelowige in 'n verhouding met God, wat die gedrag van die gelowige direk moet bepaal (Rensberger 1997). ' $n$ Persoon moet in ooreenstemming met sy identiteit optree (1 Joh 1:6; 2:4; 3:9-10), volgens die voorbeeld van Jesus (1 Joh 3:16-17), met ander woorde volgens die waarheid ( 2 en 3 Joh). Kleiner temas wat tog genoem kan word, is byvoorbeeld die belydenis van sonde (1 Joh 1:8-2:2); die sonde wat lei tot die dood (1 Joh 5:16-17), wat moontlik na die optrede van die opponente verwys (Brown 1982), en God as liefde (1 Joh 4:16).

Daar word algemeen aanvaar dat die Briewe ' $n$ eenheid van komposisie vertoon, met ander woorde, dat dit nie uit die samestelling van verskillende bronne bestaan nie. Gedurende die middel van die vorige eeu, toe bronnekritiek hoogty gevier het, het Bultmann (1973) en Dobschütz (1907) wél probeer om veral by 1 Johannes bronne te identifiseer. Bultmann het ' $n$ ontwikkeling in drie fases voorgestel, met 'n gnostiese openbaringsrede as bron, die Evangelis wat dit verwerk het, en kerklike redaksie wat die proses afgesluit het. Dobschütz (1907) het 1 Johannes 2:28-3:10 as die oudste kern van dié geskrif gesien. Hierdie benadering het egter weinig steun in die navorsing ontvang. Wat invoegings in die teks betref: Die materiaal in 1 Johannes 5:7-8 (comma Johanneum), wat in sommige vertalings en manuskripte na die Drie-eenheid, naamlik die Vader, die Woord en die Gees, verwys, verteenwoordig feitlik uitsluitlik 'n latere Latynse tekstuele tradisie. Die woorde ontbreek in feitlik 'the whole of the Greek textual tradition, including the quotations in the church fathers' (Strecker 1996). Die eerste maal wat dit as deel van die teks van 1 Johannes aangehaal word, is in die 4 de eeu in 'n Latynse teks, Liber Apologeticus (hf 4). Eers aan die einde van die 16de eeu is dit in 'n amptelike Katolieke uitgawe van die Vulgaat ingesluit.

\section{Die doel van die Johannesbriewe}

Waarom is die Briewe geskryf? In 1 Johannes 5:13 (kyk ook 1 Joh $1: 4 ; 2: 1,26)$ lees ons: 'Hierdie brief skrywe ek vir julle, sodat julle kan weet dat julle die ewige lewe het, julle wat in die Seun van God glo' - woorde wat baie aan Johannes 20:3031 herinner wat die doel van die Evangelie beskryf. Hierdie ooreenkoms word gewoonlik as ' $n$ aanduiding gesien dat daar 'n direkte verband tussen die Evangelie en die Briewe bestaan - 'n siening wat deur al die ander ooreenstemmings tussen die Evangelie en die Briewe bevestig word (kyk die lyste in Brown 1982). Die verband bestaan daarin dat 1 Johannes óf probeer om 'n verkeerde interpretasie van die Christologie van die Evangelie reg te stel en dit verder uit te werk, óf probeer verduidelik hoe die bepaalde sake wat bespreek word, reg verstaan moet word in die lig van die bedreiging en opinies van die opponente (Akin 2001). Klauck (1991) beklemtoon egter dat 1 Johannes nie as kommentaar op die Evangelie gesien moet word nie, maar wel as 'n eerste reaksie op die verstaan daarvan. Die Evangelie en Johannesbriewe moet dus in tandem gelees word (Brown 1982; Klauck 1991). Hierdie siening het natuurlik 'n impak op die bepaling van die datum en omstandighede van die ontstaan van die Briewe. 
Die Brief 1 Johannes bied egter meer as dít. Die pastorale sy van die Briewe word ook beklemtoon. Dit korrigeer die opinies van die opponente, en versterk en bemoedig die ontvangers van die Briewe (Painter 2002; Akin 2001). Die Briewe beoog om die Johannese groep van binne te stabiliseer en van buite te versterk (Klauck 1991).

Die Brief 2 Johannes kan ook gelees word as ' $n$ brief wat beoog om die gemeente te bemoedig. Die gemeente bestaan waarskynlik uit 'n groep huiskerke wat onder bedreiging van valse leraars gekom het. Nou raai die skrywer hulle aan om op ' $n$ bepaalde wyse op te tree ten einde die gevaar van die opponente die hoof te bied (Perkins 1979).

Die Brief 3 Johannes is ' $n$ brief aan Gaius, andersins onbekend, waarin Diotrefes gekritiseer word omdat hy, teen die opdragte van 'die oudste' in, weier om sendelinge te ontvang. Gaius word geprys vir sy optrede in die waarheid, en word gevra om Demetrius, 'n sendeling teenoor wie 'die oudste' en sy gemeenskap positief staan, gasvry te ontvang (Perkins 1979; kyk ook Marulli 2009).

\section{Die moontlike situasie waarin die Johannesbriewe ontstaan het}

Al drie Briewe is geskryf in 'n situasie van konflik met opponente wat die identiteit en basiese waardes van die ontvangers bedreig het. Tog bevat die Briewe nie ' $n$ duidelike beskrywing van die opponente nie (kyk Schmid 2002; Van der Merwe 2007 vir volledige besprekings). In 'n poging om die opponente te identifiseer, word die direkte opmerkings wat wél oor hulle gemaak word met sekere indirekte opmerkings gekombineer ten einde 'n volledige prentjie te skets. Die veronderstelling is natuurlik dat die direkte en indirekte opmerkings na dieselfde groep mense verwys, en dat die opmerkings op 'n geloofwaardige manier met mekaar in verband gebring kan word.

Direkte opmerkings oor die opponente word byvoorbeeld in 1 Johannes 2:18-27 en 4:1-6; 2 Johannes 7-9, en miskien 3 Johannes 9-10 gevind. Uit dié gedeeltes kan die volgende afgelei word:

- Die opponente het reeds gebreek met die Johannese groep aan wie 1 en 2 Johannes geskryf is vanweë die verskille oor die leer oor én van Jesus (Christologie), en derhalwe word kontak met hulle ontmoedig (1 Joh 2:19; 2 Joh 9-11).

- Hierdie Christologiese verskille hou verband met die Messiasskap, die mensheid (1 Joh 2:22; 4:2; 2 Joh 7) en die versoening van Jesus (1 Joh 2:2; 4:10).

- Die opponente word as antichriste en valse profete gesien wat deur valse geeste gelei word (1 Joh 2:18-19, 22; 4:3$6)$, hoewel hulle beweer dat hulle deur die Gees van God gelei word (1 Joh 4:1).

- Die opponente het skynbaar meer sukses in die wêreld as die Johannese groep (1 Joh 4:5), en mislei selfs lede van die Johannese groep (1 Joh 2:26).

Die sentrale probleem wat uit die direkte opmerkings blyk, is dus Christologies van aard.
Indirekte opmerkings wat met die opponente verband hou, word hoofsaaklik in die hipotetiese en kontrasterende opmerkings oor hul optrede aangetref (1 Joh 1:6, 8, 10; 2:4, 6, $9 ; 4: 20)$. Hierdie optrede verloën hul belydenis dat hulle God ken. Sulke indirekte opmerkings sluit die volgende in:

- Die opponente beweer dat hulle gemeenskap het met God en in die lig wandel, hoewel hulle in die duisternis leef (1 Joh 1:6; 2:9).

- Hulle beweer dat hulle God ken, in Hom bly en Hom liefhet, maar hulle hou nie God se opdragte nie en haat hulle broers (1 Joh 2:4, 6, 9; 4:20).

- Nogtans beweer hulle dat hulle nie sonde het nie, en bewys só dat hulle leuenaars is, en maak God ook ' $n$ leuenaar (1 Joh 1:6, 8, 10).

- Die opponente ontken blykbaar ook die versoenende waarde van die kruis (1 Joh 2:2; 4:10).

Die opponente was mense wat gedink het dat hulle sondeloos is, reeds gered is, die Gees besit, en in 'n verhouding met God leef. Die outeur van die Johannesbriewe huldig egter 'n teenoorgestelde mening.

Die volgende vraag is dus óf en hóé die direkte en indirekte getuienis met mekaar verband hou. Dit gaan dus oor die wyse waarop die Christologiese probleem met die uitsprake oor die gedrag van die opponente gesinkroniseer kan word. Die opponente het skynbaar geen spanning ervaar tussen hul verkeerde gedrag en hul belydenis dat hulle in gemeenskap met God leef nie. Hul Christologiese sienings ontken dat Jesus 'n mens was of dat sy mensheid en menslike aksies enige waarde het. Dieselfde blyk waar te wees van hul oordeel oor hul eie fisiese gedrag. Hul praktiese, menslike optrede word genegeer ten gunste van ' $n$ siening dat alleen die geestelike van belang is. Op dié wyse pas die Christologiese belydenis en die gedrag van die mense mooi inmekaar.

Daar is tog ' $n$ siening in die navorsing wat die direkte van die indirekte wil skei. Daar word geargumenteer dat die kontrasterende (indirekte) stellings alleen oor hipotetiese situasies handel wat moontlik in die gemeente kon ontwikkel, en dat dit nie met enige werklike of bestaande groep, byvoorbeeld die opponente, verbind moet word nie. Ander is weer van mening dat die indirekte uitsprake vir die ontvangers van 1 Johannes self of ten minste vir die lakse Christene in die Johannese groep bedoel is, aangesien die Brief aan húlle gerig is en nie aan die opponente nie (Lieu 2008). Die standpunt wat egter deur die meerderheid ondersteun word, is dat die direkte en indirekte uitsprake in verhouding tot mekaar gelees moet word. Dit veronderstel verder dat dit om een groep gaan wat weggebreek het, en dat hulle ' $n$ koherente leer aangehang het. Daar is weinig ondersteuning vir die idee dat daar meer as een groep opponente was.

Die soeke na verwante idees in die vroeë Christendom lei gewoonlik tot drie verwante sienings: Dosetisme, vroeë gnostiek, en die sienings van Serintus (kyk ook Akin 2001). Reeds aan die begin van die 2 de eeu skryf Igantius (Brief aan die Smirniote, 2:1;5:2;6:2) teen persone met naïewe Dosetistiese sienings wat na aan die Johannese profiel hier bo kom (kyk 
Strecker 1996:69-76 vir 'n uitvoerige bespreking). Ireneus (Haer. I.26.1; III.11.1) noem dat Serintus tussen die mens Jesus en die geestelike Christus onderskei het. Hul opinies word selfs vandag nog gevolg. Die bekendste ondersteuner van die gnostiese kontekstuele raamwerk vir die Johannesbriewe is Bultmann (1973). Tog wissel die opinies oor die presiese invloed van die gnostisisme op die Johannese literatuur, veral omdat die gnostiese literatuur eers later ontstaan het; nie 'n eenvormige denkbeweging met eenvormige optrede verteenwoordig nie, en eers werklik in die 2 de eeu sterk wortel geskiet het. Presiese ooreenkomste tussen die sienings van Johannes en dié van die gnostiek is nie oortuigend nie. Daar is ook ' $\mathrm{n}$ minderheidsmening dat die opponente met die libertiniste verband hou - entoesiastiese groepe uit die Pauliniese literatuur, waar dinge hand uitgeruk het (Büschel 1933; Wendt 1925).

Almal evalueer nie die impak van die skeuring in die gemeente op dieselfde wyse nie. Hoewel Lieu (2008) erken dat daar volgens 1 en 2 Johannes wel 'n skeuring in die verlede plaasgevind het, staan sy tog ' $n$ niepolemiese konteks vir die Briewe voor (kyk ook Schmid 2004). Die skeuring maak volgens haar nie die kern van die inhoud van die Briewe uit nie, en die etiese en ander sake wat aangeraak word, fokus eerder daarop om die lesers te oortuig om die standpunt wat in die Briewe aangebied word te ondersteun, en nie primêr om die opponente te kritiseer nie. Tog aanvaar die breër stroom van konsensus dat die skeuring nog lewend is in die sosiale geheue van die groep, en dat dit konkreet in die Briewe weerspieël word.

Nóg ' $n$ vraag is of die ontvangers Jode was of nie. Die groot konflik in die Evangelie was immers tussen die Johannese groep en die 'Jode'. In die Johannesbriewe gaan dit nie oor die 'Jode' búite die groep nie, maar oor krisisse ín die groep self. Was hierdie groep ook Joods? Die meerderheidsiening is dat die groep meer nie-Joods as Joods was (Klauck 1991; Painter 2002). Tog word die Kumran-gemeenskap dikwels as godsdienshistoriese raamwerk met die Briewe verbind (bv. Lieu 2008; Menken 2010), vanweë byvoorbeeld die dualisme en sektariese mentaliteit van dié groep. Die opponente word gesien as Jode wat terugbeweeg na hul wortels in die Judaïsme (Lieu 2008; Wurm 1903). Griffith (2002) baseer sy siening op die manier waarop 1 Johannes eindig, naamlik deur na 'afgode' te verwys - 'n veelseggende term in die Jodedom.

\section{Aan wie en deur wie is die Johannesbriewe geskryf?}

Die Briewe is aan mense geskryf wat volgens die outeur sy meer 'ortodokse' opinies aanvaar en deel (Klauck 1991). Daar is 'n ou tradisie dat sowel die Johannese groep as die outeur in Efese gewoon het. Hierdie tradisie word teruggevoer na die einde van die 2de eeu, toe Ireneus in Haer III.11.1,2 na die konfrontasie tussen Johannes en Serintus in Efese verwys het. Hierdie siening word vandag steeds algemeen aanvaar, hoewel daar ook ander moontlikhede is wat met minder entoesiasme aangebied word. Areas soos Jerusalem,
Samaria of die bolope van die Jordaan word onder meer as alternatiewe aangebied.

Die drie Johannesbriewe is nie aan dieselfde groepe gerig nie, maar die teikengroepe hét waarskynlik oorvleuel. Die Brief 3 Johannes is aan 'n individu, Gaius, geskryf in verband met probleme met Diotrefes, wat nie die gesag van 'die oudste' wou aanvaar nie. Dit wil voorkom of Diotrefes Christelike gemeenskappe om plaaslike leraars wou konsolideer, wat miskien kon dui op die ontwikkeling van 'n groep wat nie noodwendig met die skeurders saamval nie.

Die ontvangers van 2 Johannes word die 'uitverkore vrou en haar kinders' genoem, wat deur sommige as 'n werklike vrou en deur ander as 'n figuurlike verwysing na die plaaslike gemeente beskou word.

Die Brief 1 Johannes het ' $n$ groter groep in gedagte, naamlik die mense wat ná die skeuring agtergebly het. Die skeuring en die gevolge daarvan het hulle wel direk geraak, maar hulle het by die leer van 1 en 2 Johannes bly staan (Perkins 1979). Hulle het die outeur as gesaghebbend beskou en het skynbaar in 'n goeie verhouding met hom gestaan. Hy spreek hulle graag as 'kindertiies' of 'geliefdes' (1 Joh 2:12, $18 ; 4: 1,7 ; 3$ Joh 5, 11) aan. Spesiale klem word gelê op hul verhouding met die Gees, wat die funksionele naam van 'salwing' dra (1 Joh 2:26-27). Daar is sienings dat hierdie sterk klem op die Gees en dat niemand hulle hoef te leer nie daarop dui dat van die ontvangers se leiers saam met die skeuring wegbeweeg het. Verder toon hierdie groep tipiese eienskappe van sektes, of eerder 'n societas (Perkins 1979). 'n Societas is ' $n$ doelbewuste assosiasie van mense wat om dieselfde doel kragte saamsnoer. Die Johannese groep wat in die Briewe weerspieël word, tree op as groep; het teen die wêreld gedraai (1 Joh 2:15-17), en fokus op hul innerlike verhoudings (1 Joh 2:10-11), terwyl hulle aan hul eie sienings as die enigste waarheid vashou (1 Joh 4:6). Gedagtig aan die inligting wat uit 2 en 3 Johannes na vore kom, lyk dit of die Johannese groep uit ' $n$ aantal plaaslike huiskerke bestaan wat sosiaal aan mekaar verbonde was en mekaar ondersteun het, ook wat sendelinge betref. 'Die oudste' tree as gesaghebbende leier op, hoewel die episode met Diotrefes in 3 Johannes wys dat sy leierskap nie absoluut aanvaar is nie, maar selfs teengestaan is. Tog skryf hy met gesag van sy gemeente aan die ander Christene; bied hy advies, en beoog hy selfs om hulle te besoek om belangrike sake met hulle te bespreek (1 Joh 12; 3 Joh 13).

Maar wie was die outeur(s) van die Briewe? Dít is 'n saak wat in die Johannese diskussies deeglik aandag ontvang, sonder dat daar werklik konsensus bereik word. Vir baie eeue was die konsensus dat Johannes, die seun van Sebedeus, ten minste 1 en miskien 2 Johannes geskryf het. Hierdie siening is gebaseer op die opmerkings van Ireneus (Haer III.1.1), wat die Evangelie en twee Briewe met mekaar verbind het. Sedert die 1800's word hierdie siening egter bevraagteken met ' $n$ hele aantal alternatiewe voorstelle, wat strek van die aanvaarding van ' $n$ enkele outeur vir die Evangelie en Johannesbriewe, tot verskillende outeurs vir elkeen. 
Opinies oor die outeurskap word bepaal deur die wyse waarop daar met die beskikbare inligting omgegaan word. Diegene wat klem lê op die ooreenkomste tussen die Briewe en die Evangelie (bv. die woordeskat, styl, teologiese perspektiewe - vir lyste, kyk Brown 1982 en Holtzmann 1881-1882; kyk Kim 2003 vir oorsig van navorsing) neig om een outeur vir die Briewe en Evangelie te aanvaar (Kruse 2000; Yarbrough 2008; Menken 2010) en om die outeur met Johannes, die seun van Sebedeus, te verbind, veral as 1 Johannes 1:1-4 nog as bewys gesien word dat die outeur 'n ooggetuie was. Dit is interessant dat hierdie standpunt in die afgelope tyd heelwat steun vanuit meer konserwatiewe Amerikaanse kringe ontvang. Die verskille tussen die Briewe onderling en tussen die Briewe en die Evangelie word verklaar op grond van die situasie wat verander het (nie meer ' $n$ konflik met Jode búite die gemeente nie, maar met lidmate ín die gemeente) en die genre wat verskil (van 'n Evangelie na Briewe).

Aan die ander kant, as die verskille tussen die Briewe en die Evangelie op die voorgrond geplaas word (bv. versoening, eskatologie, die identiteit van die Parakleet, God wat funksies van Jesus oorneem), is die gevolgtrekking gewoonlik dat verskillende outeurs vir die verskillende dokumente verantwoordelik is. Hierdie gevolgtrekking het twee resultate. Eerstens word verskillende kombinasies outeurs vir die verskillende dokumente voorgestel, byvoorbeeld 'n afsonderlike outeur vir elke dokument; dieselfde outeur vir 2 en 3 Johannes, maar iemand anders vir 1 Johannes (Lieu 2008); dieselfde outeur vir 1 en 2 Johannes, of dieselfde outeur vir al drie Briewe, hoewel iemand anders as die persoon wat die Evangelie geskryf het (Dodd 1946). Tweedens, aangesien verskillende outeurs voorgestel word, moet daar natuurlik na verskillende moontlike skrywers gesoek word. Aan voorstelle is daar nie ' $n$ tekort nie: Dit sluit in die Evangelis; die redaktor van die Evangelie; 'n onbekende ouderling; Johannes, die Seun van Sebedeus; die presbiter Johannes van Klein-Asië; 'n onbekende volgeling van die Geliefde Dissipel, ensovoorts. Daar kan ook sprake wees van verwarring, byvoorbeeld dat die Johannes waarvan Papias (volgens Eusebius) aan die begin van die 2de eeu praat, in die tradisie met Johannes, die seun van Sebedeus, verwar is. Die tradisie glo dus dit is Johannes, die seun van Sebedeus, maar eintlik is dit iemand anders. Die hipotetiese aard van die debat open natuurlik die deur vir verbeeldingrykheid en oorspronklikheid, sodat die scenario's van hoe die gemeentes sou ontwikkel het en wie wat wanneer geskryf het soms bietjie oordadig voorkom, wat konsensus natuurlik verder bemoeilik.

Twee verdere punte moet hier genoem word:

1. Die Brief 1 Johannes is anoniem, en Lieu (2008) argumenteer dít is omdat die outeur hom agter die gesag van die teks self wou verberg en op dié wyse 'onsigbaar' wou raak - ten spyte daarvan dat hy waarskynlik aan die ontvangers bekend was. Dié standpunt oortuig nie almal nie, maar moet tog as ' $n$ moontlikheid oorweeg word.

2. Ook bestaan daar ten minste ' $n$ groot mate van erkenning vir die feit dat, as die Briewe nie deur dieselfde outeur geskryf is nie, die ooreenkomste in inhoud, taal en styl tog die gevolgtrekking toelaat dat die dokumente in dieselfde tradisie veranker is of tot dieselfde groep met ' $n$ gemeenskaplike wêreldbeeld behoort.

Dít is waarskynlik die naaste wat 'n mens aan 'n konsensus sou kon kom.

\section{Wanneer is die Johannesbriewe geskryf?}

Daar word gewoonlik in debatte aanvaar dat die drie Briewe kort na mekaar geskryf is, binne die bestek van hoogstens tien jaar. Die datering van die Briewe hang onder andere af van goed soos die datering van die Evangelie; die moontlikheid dat Johannes, die seun van Sebedeus, oud kon geword het, of die eksterne inligting oor wanneer daar die eerste maal na die Briewe verwys word. Die verskeie faktore lei tot ' $n$ ingewikkelde diskussie, wat hier net in breë trekke weergegee kan word.

Die meerderheidsmening is dat om en by $100 \mathrm{nC}$ die mees aanvaarbare datum vir die ontstaan van die Evangelie en Johannesbriewe sou wees. Dié datum word as waarskynlik aanvaar, aangesien dit min of meer die datum vir die finale redaksie van die Evangelie kon wees, omdat Ireneus (Haer III.1.1) noem dat Johannes in Efese gebly het tot en met die bewind van Trajanus (98-117 nC). Dit sou natuurlik beteken dat hy oud geword het en nog die dokumente kon geskryf het, en dat dit genoeg tyd laat vir die ontwikkelings in die gemeente waarvan ons in die Briewe lees. As dít die geval is, moet die fyner detail nog uitgewerk word. Waarop eerstens gelet word, is dat die Evangelie 'n lang ontwikkelingsgeskiedenis het, wat beteken dat die kerninhoud van die Evangelie lank voor die skryf van die Briewe reeds beskikbaar was, en hoogs waarskynlik ook in die Johannese groep bekend was (Klauck 1991). Dit gaan dus oor die laaste fases (redaksie) van die Evangelie. As die finale redaksie van die Evangelie tydens of miskien net ná die skryf van 1 en 2 Johannes plaasgevind het (Brown 1982), is ' $\mathrm{n}$ datum voor $100 \mathrm{nC}$ en selfs nog in die middel van die jare $90 \mathrm{nC}$ moontlik. Die finale redaksie van die Briewe kon dan saamgeval het met die skryf van 3 Johannes (Brown 1982). Daar is ook diegene wat die skryf van al drie Johannesbriewe voor die finale redaksie van die Evangelie plaas, wat ' $n$ nog vroeër datum moontlik maak (Strecker 1996; Schnelle 1999). As die Briewe egter ná die finale redaksie geskryf is, sou ' $\mathrm{n}$ datum om en by 100-110 nC gepostuleer kon word. Robinson (1985) se suggestie van ' $\mathrm{n}$ datum in die jare $60 \mathrm{nC}$ word nie ernstig opgeneem nie, terwyl ander stemme ten gunste van 'n datum in die middel van die 2de eeu opgeklink het (Baur 1848 het selfs 170/180 $\mathrm{nC}$ voorgestel). So ' $\mathrm{n}$ laat datum geniet egter nie baie steun nie, aangesien die eksterne getuienis dit onwaarskynlik maak. Polikarpus, Ignatius en Justinus het moontlik almal in die eerste deel van die 2 de eeu van 1 Johannes geweet en toespelings daarop gemaak. Teen $180 \mathrm{nC}$ maak Ireneus (Haer III.16.5, 8) reeds melding van die Johannesbriewe.

\section{Die volgorde van die Johannesbriewe}

Die soeklig word ook soms gewerp op die volgorde waarin die drie Briewe geskryf is, veral omdat dit met die scenario's 
vir die ontwikkeling van die Johannese groep en die konflik verband hou. Ook hier is ' $n$ meningsverskil. Sommige beweer byvoorbeeld dat die volgorde van die skryf van die Briewe 3-21 was, omdat so 'n volgorde die ontwikkeling van die konflik die beste illustreer. In 3 Johannes sien die outeur nog kans om met die moeilikheidmakers te kom praat; in 2 Johannes word die opponente al die huise verbied, en in 1 Johannes het die skeuring klaar plaasgevind. Lieu (2008) dink ook dat 3 Johannes voor 2 Johannes geskryf is, omdat laasgenoemde op eersgenoemde gemodelleer sou wees. Ander verkies weer die volgorde 1-2-3. Menken (2010) argumenteer dat dié volgorde die aard van die materiaal die beste verklaar. In 1 Johannes word die breë teoretiese raamwerk beskryf; in 2 Johannes gaan dit oor praktiese advies, en in 3 Johannes oor 'n spesifieke fokus op 'n spesifieke probleem. Ook oor hierdie vraag is daar nie volle klaarheid nie.

\section{Die ontvangs van die Johannesbriewe in die vroeë geskiedenis}

'n Interessante verskynsel is dat alle tekens van die bestaan van 'n Johannese groep in die 2de eeu verdwyn, hoewel hul dokumente invloedryk bly (Hengel 1989). Polikarpos (Brief aan die Filippense 7:1) haal oënskynlik uit 1 Johannes $(3: 8 ; 4: 2)$ aan, terwyl Justinus (Dialoog met Trifo 123:9) waarskynlik na 1 Johannes 3:1 verwys. Ireneus (Teen dwaalleraars III.16.5,6) is die eerste een wat direk uit 1 Johannes aanhaal, en dít het die weg vir die verdere gebruik van die Brief gebaan. Eusebios (Kerkgeskiedenis 3.39.17) noem dat Papias (wat in die eerste deel van die 2 de eeu geleef het) van 1 Johannes gebruik gemaak het. Ireneus het moontlik ook na 2 Johannes verwys, maar 3 Johannes begin eers in die 4de eeu werklik aandag trek.

Wat van kanonisering? Weereens het die geskiedenis van 1 Johannes anders as dié van die ander twee Briewe verloop. Vanaf die vroegste lyste van gesaghebbende dokumente was 1 Johannes reeds daar. Die Kanon van Muratori (aan die einde van die 2de, begin van die 3de eeu) noem twee Briewe (waarskynlik 1 en 2 Johannes), maar haal 1 Johannes 1:1 en 4 aan (reëls 26-34). Kerkvaders soos Origines en Eusebios het die gesag van 1 Johannes erken, maar was skepties oor die outentisiteit van die ander twee Briewe. Dié situasie het tot die 4 de eeu voortgeduur.

\section{Slot}

In die afgelope paar dekades het heelparty nuwe kommentare op die Briewe die lig gesien (kyk Barclay 2002; Culpepper 1998; Culy 2004; Grayston 1984; Holden 1994; Holladay 2005; Johnson 1993; Kysar 1986; Lieu 1991; Marshall 1978; Smith 1991; Stott 1988; Uebele 2001; Von Wahlde 1990; Vouga 1990). Kommentare het veral uit die meer Evangeliese Amerikaanse hoek gekom wat die tradisionele standpunte verdedig. Die meesterwerke van Brown (1982), Klauck (1991), Schnackenburg (1992) en andere domineer egter die ondersoekterrein, aangesien hul analises so deeglik is. Lieu (2008) het probeer om die Briewe vanuit enkele ander perspektiewe te lees, maar het nie daarin geslaag om die breë Johannese ondersoekgilde te oorreed om haar opinies na te volg nie. Daar was dus geen groot veranderings of belangrike paradigmaskuiwe op die ondersoekterrein nie, hoewel die meeste eksegetiese analises wat wél in die kommentare beskikbaar is, van goeie gehalte is. Na die navorser se mening bied die Johannesbriewe nog vrugbare terrein vir sosiale ondersoeke sowel as vir resente metodologiese invalshoeke.

\section{Erkennings}

Hierdie artikel word opgedra aan my kollega, Andries van Aarde, vir sy bydrae tot die Nuwe-Testamentiese wetenskap.

\section{Literatuurverwysings}

Akin, D.L., 2001, 1,2,3 John: An exegetical and theological exposition of Holy Scripture, Broadman \& Holman, Nashville. (NAC 38).

Barclay, W., 2002, The letters of John and Jude, Westminster John Knox, Louisville.

Baur, F.C., 1848, 'Die johanneischen Briefe, Ein Beitrag zur Geschichte des Kanons', Theologische Jahrbücher 7, 293-337.

Brown, R.E., 1982, The Epistles of John, Doubleday, New York. (AB 30).

Brown, R.E., 1997, An introduction to the New Testament, ABRL, Doubleday, New York.

Bruce, F.F., 1979, The Epistles of John, Eerdmans, Grand Rapids.

Bultmann, R., 1973, The Johannine epistles, Fortress, Philadelphia.

Büschel, F., 1933, Die Johannesbriefe, Evangelische Verlagsanstalt, Leipzig.

Culpepper, R.A., 1998, The gospel and letters of John, Abingdon, Nashville.

Culy, M.M., 2004, I, II, III John: A handbook on the Greek text, Baylor University Press, Waco.

deSilva, D., 2004, An introduction to the New Testament: Contexts, methods \& ministry formation, IVP, Downers Grove.

Dobschütz, E. von, 1907, 'Johanneische Studien I', Zeitschrift für Neutestamentliche Wissenschaft 8, 1-8. doi:10.1515/zntw.1907.8.1.1

Dodd, C.H., 1946, The Johannine epistles, Harper\&Row, NY.

Grayston, K., 1984, The Johannine Epistles, NCB, Grand Rapids.

Griffith, T., 2002, Keep yourselves from idols: A new look at 1 John, JSNTSup 233, Sheffield Academic Press, London.

Guthrie, D., 1990, New Testament introduction, IVP, Downers Grove.

Hengel, M., 1989, The Johannine question, SCM, London.

Holden, J.L., 1994, A commentary on the Johannine epistles, A\&C Black, London.

Holladay, C.R., 2005, A critical introduction to the New Testament: Interpreting the message and meaning of Jesus Christ, Abingdon, Nashville.

Holtzmann, H.J., [1881]1882, 'Das Problem des ersten johanneischen Briefes in seinem Verhältniss zum Evangelium', Jahrbuch für Protestantische Theologie 7(8), 690-712/128-152, 316-342, 460-485.

Johnson, T.F., 1993, 1, 2, and 3 John, Hendrickson, Peabody. (NIBC).

Kim, M.G., 2003, Zum Verhältnis des Johannesevangeliums zu den Johannesbriefen: Zur Verfasserschaft der 'johanneischen' Schriften in der Forschung, Peter Lang, Frankfurt.

Klauck, H.J., 1991, Der Erste Johannesbrief, EKK XXIII/1, Benziger/Neukirchener, Zürich/Neukirchen-Vluyn.

Köstenberger, A.J., 2009, A theology of John's gospel and letters, Zondervan, Grand Rapids.

Kruse, C., 2000, The letters of John, Eerdmans, Grand Rapids.

Kysar, R., 1986, I,II,III John, Augsburg, Minneapolis.

Lieu, J.M., 1991, The theology of the Johannine epistles, CUP, Cambridge. doi:10.1017/ CBO9780511621376

Lieu, J.M., 2008, I, II, and III John: A commentary, Westminster John Knox, Louisville.

Lohmeyer, E., 1928, 'Über Aufbau und Gliederung des ersten Johannesbriefes', Zeitschrift für Neutestamentliche Wissenschaft 27, 225-263. doi:10.1515/ zntw.1928.27.2.225

Marulli, L., 2009, A letter of recommendation? A closer look at Third John's 'Rhetorical Argumentation', Biblica 90(2), 203-223.

Marshall, I.H., 1978, The epistles of John, Eerdmans, Grand Rapids. (NICNT).

Menken, M., 2010, 1,2 en 3 Johannes: Een praktische bijbelverklaring, T\&T, Kok, Kampen.

Painter, J., 2002, 1,2, and 3 John, Sacra Pagina 18, Liturgical, Collegeville, Minnesota. Perkins, P., 1979, The Johannine epistles, Michael Glazier, Wilmington, DE. Rensberger, D., 1997, 1 John, 2 John, 3 John, Abingdon, Nashville.

Robinson, J.A.T., 1985, The priority of John, SCM, London. 
Schmid, H., 2002, Gegner im 1 Johannesbrief? Zu Konstruktion und Selbsreferenz im johanneischen Sinnsystem, Kohlhammer, Stuttgart.

Schmid, H., 2004, 'How to read the First Epistle of John nonpolemically', Biblica 85(1), 24-41.

Schnackenburg, R., 1992, The Johannine epistles, Crossroads, New York.

Schnelle, U., 1999, Einleitung in das Neue Testament, Vandenhoeck \& Ruprecht, Göttingen.

Smalley, S.S., 1984, 1,2,3 John, Word, Waco. (WBC 51).

Smith, D.M., 1991, First, second, and third John, John Knox, Louisville.

Stott, J.R.W., 1988, The letters of John, Eerdmans, Grand Rapids.

Strecker, G., 1996, The Johannine letters, Hermeneia, Fortress, Minneapolis.

Uebele, W., 2001, Viele Verfuhrer sind in die Welt ausgegangen: Die Gegner in den Briefen des Ignatius von Antiochien und in den Johannesbriefen, Kohlhammer Stuttgart.
Van der Merwe, D.G., 2007, 'The identification of the elements that caused a schism in the Johannine community at the end of the first century CE', HTS Teologiese Studies/Theological Studies 63(3), 1149-1169.

Van der Watt, J.G., 2007, Introduction to the gospel and letters of John, T\&T Clark, London.

Von Wahlde, U.C., 1990, 1 John and the struggle for the Johannine tradition, Paulist, New York.

Vouga, F., 1990, Die Johannesbriefe, Tübingen, Mohr.

Wendt, H.H., 1925, Die Johannesbriefe und das johanneische Christentum, Buchhandlung des Waisenhauses Franckesche Stiftungen, Halle.

Wengst, K., 1978, Der erste, zweite und dritte Brief des Johannes, Mohn, Gütersloh. (ÓTK 16).

Wurm, A., 1903, Die Irrlehrer im ersten Johannesbrief, Herder, Freiburg.

Yarbrough, R.W., 2008, 1,2, and 3 John, Baker, Grand Rapids. 